\title{
Research on the Influence Mechanism of Psychological Safety on Leaders' Ambidexterity Based on Experimental Analysis
}

\author{
1, 2, ${ }^{3}$ School of Economics and Management, Southeast University, Nanjing, China \\ ${ }^{4}$ High School Affiliated To Nanjing Normal University \\ ${ }^{I}$ wu.chaolong@foxmail.com \\ 22vhongjiang@seu.edu.cn \\ ${ }^{4}$ ctx2192946756@163.com
}

ChaoLong $\mathrm{Wu}^{1}{ }^{1}$, HongJiang $\mathrm{Lv}^{2}$, Lufeng $\mathrm{He}^{3}$, Tianxiao Cheng ${ }^{4}$

\begin{abstract}
The rapid development of information technology and the Internet makes it easier for leaders and employees to have more connections. Therefore, it is very important for organizations and leaders to study the impact of the leadership situation on the leaders' behaviors. The purpose of this paper is to explore the impact mechanism of leaders' Psychological Safety on Leaders' Ambidexterity. 115 leaders and all 527 direct subordinates are selected for empirical test. The results show that leaders' Psychological Safety has a significant positive impact on Leaders' Ambidexterity. This study theoretically analyzes the influence mechanism of leaders' Psychological Safety on Leaders' Ambidexterity, which provides a new theoretical framework for follow-up research; In practice, it also provides specific guidance for leaders.
\end{abstract}

Keywords: Psychological Safety, Leaders'Ambidexterity

\section{INTRODUCTION}

The ambidexterity of individual and organization is of great importance today. If enterprises want to maintain their competitiveness in the dynamic environment, they must carry out exploratory and exploitative innovation activities at the same time [1][2]. Organizational ambidexterity mainly comes from leaders at all levels of the organization ${ }^{[1]}$, but the existing researches on Leaders' Ambidexterity are slightly insufficient. Although it involves the impact of leaders' own characteristics and their relationship with subordinates on their own ambidexterity behavior [3], relevant researches still focus on the impact of superior leaders on executives' ambidexterity behavior in the organization and the impact of external environment on employees' Ambidexterity at all levels in the organization ${ }^{[4]}$.

Based on this, this study aims to achieve the following objectives: The first one is to test the relationship between Psychological Safety and Leaders' Ambidexterity, hoping to explore the impact mechanism of Psychological Safety on Leaders' Ambidexterity, and provide a new theoretical framework for follow-up research; In practice, it also provides specific guidance for leaders.

\section{RESEARCH HYPOTHESIS}

Relevant studies have shown that Psychological Safety has a significant impact on the generation of new ideas ${ }^{[5]}$. In addition, Psychological Safety can not only promote individuals to acquire more new knowledge, but also promote individuals' participation in creative works [6]. The promotion of Psychological Safety to leaders' learning behavior encourages leaders to obtain more new knowledge. At the same time, Psychological Safety also promotes leaders to make use of new knowledge and actively participate in the creative work of practicing new knowledge and ideas. In addition to the impact on learning behavior and participation in creative works, Baer and Frese [7] found that Psychological Safety can positively affect process innovation, so as to promote the improvement of corporate performance. ABC theory holds that the individual belief, which is the individual's inner 
explanation and view of events and situations, is the reason for the individual to produce or make a certain behavior. The leader's Psychological Safety, as the leader's self-interpretation of the external situation, especially the subordinates' evaluation, is the leader's belief about the events they encountered, which will really induce leaders to produce the final behavior results.

Therefore, we believe that the leader's Psychological Safety is the leader's perception of others at work, especially the evaluation of subordinates, and the leader's perception of his external interpersonal environment. As the leader's perception of his sense of support and trust in his team subordinates, when the external situational characteristics activate the cognitive emotional unit, it will directly promote the leader's response behavior, that is, the Leaders' Ambidexterity, positively promote the leaders' exploratory innovation behavior, and positively affect the leaders' exploitative innovation behavior, and maintain a balance between the two.

Based on the above analysis, we can draw hypothesis 3: Leaders' Psychological Safety has a significant positive impact on Leaders' Ambidexterity.

\section{RESEARCH DESIGN}

\subsection{Research Object}

This study selected 115 managers from 37 large, medium and small enterprises engaged in energy, machinery, transportation and other industries in Jiangsu, Zhejiang and Anhui.

In this paper, the data were collected by questionnaire and interview. All the scales were taken from the foreign maturity scale. The questionnaire includes three parts: Department overall network variables (Department power network, Department Psychological Safety network), leadership behavior and psychological variables (Leaders' Ambidexterity) and demographic characteristic variables.

In this study, 756 questionnaires were distributed and 642 valid questionnaires were recovered, including 115 leaders and 527 grass-roots employees. The effective rate was $84.79 \%$. The average age of the survey sample is 40.55 years $(\mathrm{SD}=8.13)$, and the average length of service is 13.48 years $(\mathrm{SD}=8.77)$.

\subsection{Research Tool}

- Psychological Safety. The three item Psychological Safety network scale developed by Edmondson ${ }^{[8]}$ was used and filled in by the leaders and employees in the team.

- Leaders' Ambidexterity. The 11 item scale developed by MOM et al. ${ }^{[4]}$ was used and self-rated by leaders. After inspection, one item with factor load less than 0.5 was deleted.

- Control variables. In order to prevent other variables from affecting this study, this study controls the leader's gender, age, education level and working years.

\section{EMPIRICAL RESULTS AND ANALYSIS}

\subsection{Descriptive Statistics}

Table 1 shows the mean, standard deviation and correlation coefficient of all relevant variables in this study. It can be seen from the data in the table that there is a significant positive correlation between Psychological Safety and Leaders' Ambidexterity ( $\mathrm{r}=$ $0.26, \mathrm{P}<0.01)$, which preliminarily supports the hypothesis.

Table 1 descriptive statistics

\begin{tabular}{|c|c|c|c|c|}
\hline Variable & $\begin{array}{l}\text { Average } \\
\text { Value }\end{array}$ & SD & 1 & 2 \\
\hline $\begin{array}{c}\text { Psychological } \\
\text { Safety }\end{array}$ & 0.68 & 0.34 & 1 & \\
\hline $\begin{array}{c}\text { Leaders' } \\
\text { Ambidexterity }\end{array}$ & 33.42 & 8.83 & $0.26^{* \star}$ & 1 \\
\hline \multicolumn{5}{|c|}{$\begin{array}{l}\text { *. At the } 0.05 \text { level (two tailed), the correlation was } \\
\text { significant, }{ }^{* *} \text {. At the } 0.01 \text { level (two tailed), the } \\
\text { correlation was significant. }\end{array}$} \\
\hline
\end{tabular}

\subsection{Hypothesis Test}

According to the analysis results in Table 2, the data in the table shows that Psychological Safety has a significant positive impact on Leaders' Ambidexterity (model 2, $\beta=0.24, \mathrm{P}<0.05$ ), the hypothesis was supported.

Table 2 test of direct effect and intermediary effect

\begin{tabular}{|c|c|c|c|}
\hline \multirow{2}{*}{\multicolumn{2}{|c|}{ Variable }} & \multicolumn{2}{|c|}{$\begin{array}{c}\text { Leaders' } \\
\text { Ambidexterity }\end{array}$} \\
\hline & & M1 & M2 \\
\hline \multirow{4}{*}{ Control Variable } & Sex & -0.09 & -0.10 \\
\hline & Age & 0.23 & 0.22 \\
\hline & Working Years & -0.18 & -0.21 \\
\hline & Education & -0.04 & -0.04 \\
\hline $\begin{array}{l}\text { Independent } \\
\text { Variable }\end{array}$ & $\begin{array}{c}\text { Psychological } \\
\text { Safety }\end{array}$ & & $0.24^{*}$ \\
\hline \multirow{4}{*}{ Regression Results } & Value of $F$ & & \\
\hline & $\mathrm{R}^{2}$ & & \\
\hline & Adjusted $\mathrm{R}^{2}$ & & \\
\hline & $\triangle R^{2}$ & & \\
\hline
\end{tabular}




\begin{tabular}{|l|c|c|c|}
\hline & $\begin{array}{c}\text { Mean Value of } \\
\text { VIF }\end{array}$ & $<10$ & $<10$ \\
\hline
\end{tabular} \begin{tabular}{l}
${ }^{*}$. At the 0.05 level (two tailed), the correlation was significant, , ${ }^{* *}$. \\
At the 0.01 level (two tailed), the correlation was significant. \\
\hline
\end{tabular}

\section{CONCLUSIONS}

\subsection{Research Conclusion}

This study takes 115 leaders as the research object to explore the influence mechanism of Psychological Safety on Leaders' Ambidexterity. The results show that leaders' Psychological Safety has a positive impact on Leaders' Ambidexterity.

\subsection{Theoretical Significance}

The relationship and interaction between leaders and subordinates have always been the focus of management research. Previous researchers mostly discussed the emergence of Leaders' Ambidexterity from the perspectives of leader-subordinate interaction and the perspectives of subordinates. From the level of leaders, this study explores the reactive behavior of leaders when they are in the workplace situation, which enriches the understanding of the antecedents and mechanisms of Leaders' Ambidexterity.

\subsection{Management Enlightenment}

Enterprises need to pay attention to cultivating the Psychological Safety of employees at all levels in management practice. This study found that leaders' Psychological Safety can positively promote Leaders' Ambidexterity. Therefore, enhancing leaders' psychological safety can directly promote leaders to make ambidexterity behavior, so as to promote the development of the whole organization in the direction of innovation and exploration.

\subsection{Limitations and Prospects}

This study still has some limitations. Firstly, there are two deficiencies in data collection. First, employees may be in shame and psychological bias when filling in the online questionnaire, so they are unwilling to fill in the questionnaire, which affects the authenticity of the data; Second, the data in this study are collected at a single time point, which will have some impact on the persuasion of this study. In addition, the leaders referred to in this study are more middle-level leaders in the team. When collecting data, it is considered that the middle-level leaders are closer to the grass-roots level, and the data collection will be more authentic. Therefore, the relevant situation of senior leaders has not been taken into account, which is also a direction that needs to be further explored in the future.

\section{REFERENCES}

[1] Gibson C B , Birkinshaw J . The Antecedents, Consequences, and Mediating Role of Organizational Ambidexterity[J]. Academy of Management Journal, 2004, 47(2):209-226.

[2] Raisch S , Birkinshaw J , Probst G , et al. Organizational Ambidexterity: Balancing Exploitation and Exploration for Sustained Performance[J]. Organization Science, 2009, 20(4):685-695.

[3] BONESSO S, GERLI F, SCAPOLAN A. The individual side of ambidexterity: Do individuals' perceptions match actual behaviors in reconciling the exploration and exploitation trade-off?[J]. European Management Journal, 2014,32(3): 392-405.

[4] MOM T J M, van den BOSCH F A J, VOLBERDA $\mathrm{H}$ W. Understanding Variation in Managers' Ambidexterity: Investigating Direct and Interaction Effects of Formal Structural and Personal Coordination Mechanisms[J]. Organization Science, 2009,20(4): 812-828.

[5] Nora Madjar,Rowena Ortiz-Walters. Trust in Supervisors and Trust in Customers: Their Independent, Relative, and Joint Effects on Employee Performance and Creativity[J]. Human Performance,2009,22(2).

[6] KARK R, CARMELI A. Alive and creating: the mediating role of vitality and aliveness in the relationship between Psychological Safety and creative work involvement[J]. Journal of Organizational Behavior, 2009,30(6): 785-804.

[7] Markus Baer, Michael Frese. Innovation is not enough: climates for initiative and Psychological Safety, process innovations, and firm performance[J]. Journal of Organizational Behavior,2003,24(1).

[8] Edmondson A. Psychological Safety and Learning Behavior in Work Teams $[\mathrm{J}]$. Administrative Science Quarterly. 1999, 44(2): 350-383. 